\title{
Isolated low grade pilocytic astrocytoma of the optic nerve in the elderly: case report
}

\author{
Astrocitoma pilocítico de baixo grau do nervo óptico em adultos: relato de caso
}

\author{
Erika Hoyama ${ }^{1}$ \\ Antonio Augusto Velasco e Cruz ${ }^{2}$ \\ Benedicto Oscar Colli ${ }^{3}$ \\ João Roberto de Matos ${ }^{4}$ \\ FernandoChahud ${ }^{5}$
}

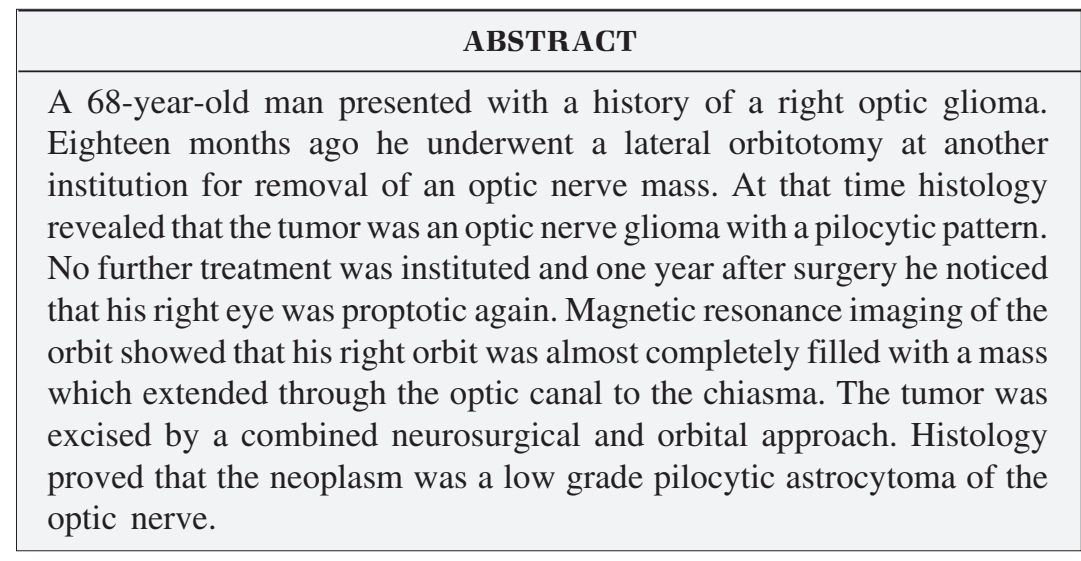

Keywords: Optic nerve glioma/diagnosis; Astrocytoma/diagnosis; Optic nerve/pathology; Magnética resonance imaging; Aged; Case reports [Publication type]

Trabalho realizado no Departamento de Oftalmologia, Otorrinolaringologia e Cirurgia de Cabeça e Pescoço da Faculdade de Medicina de Ribeirão Preto, Universidade de São Paulo - USP - Ribeirão Preto (SP) - Brasil.

${ }^{1}$ MD, Oculoplastic Unit, Hospital de Olhos de Londrina, Londrina (PR) - Brazil.

${ }^{2} \mathrm{PhD}$, Professor and Head of the Oculoplastic and Orbit Division of the Department of Ophthalmology, Otorhinolaryngology and Head and Neck Surgery, Faculdade de Medicina de Ribeirão Preto - Universidade de São Paulo - USP - Ribeirão Preto (SP) - Brazil.

${ }^{3} \mathrm{PhD}$, Professor and Head of the Neurosurgery Division, Department of Surgery, Faculdade de Medicina de Ribeirão Preto - Universidade de São Paulo - USP - Ribeirão Preto (SP) - Brazil.

${ }^{4}$ MD, Radiology Unit, Hospital Oswaldo Cruz, Palmas (TO) - Brazil.

MD, Professor of the Department of Pathology, Faculdade de Medicina de Ribeirão Preto - USP - Ribeirão Preto (SP) - Brazil.

Corresponding author: Antonio Augusto V. Cruz. Departamento Oftalmologia, Otorrinolaringologia e Cirurgia de Cabeça e Pescoço. Faculdade de Medicina de Ribeirão Preto - USP - Hospital das Clínicas-Campus.

Av. Bandeirantes, 3.900 - Ribeirão Preto (SP)

CEP 14049-900

E-mail: aavecruz@ fmrp.usp.br

Recebido para publicação em 08.01.2007

Última versão recebida em 29.08.2007

Aprovação em 02.09.2007

Nota Editorial: Depois de concluída a análise do artigo sob sigilo editorial e com a anuência do Dr. Sérgio Burnier sobre a divulgação de seu nome como revisor, agradecemos sua participação neste processo.

\begin{abstract}
INTRODUCTION
Gliomas of the optic nerve are uncommon, comprising $1-5 \%$ of intracranial astrocytomas and $1.5-3.5 \%$ of all orbital tumors. They occur most frequently in children and young adults, $75 \%$ of them in the first decade and $90 \%$ in the first two decades of life ${ }^{(1-3)}$. They may be confined to the optic disc and nerve $(25 \%)$ or may involve the chiasma with or without the optic nerves in $20-40 \%$ of $\operatorname{cases}^{(1-2)}$. We describe here a case of an isolated pilocytic astrocytoma of the optic nerve in an aged adult, which was incompletely excised and recurred as an extensive mass in the orbit.
\end{abstract}

\section{CASE REPORT}

A 68-year-old man presented with a 3-month history of progressive proptosis and decreased vision to blindness in the right eye. He had been first seen 18 months ago at another institution where an orbital MRI showed an enlarged and patchy contrast-enhanced right optic nerve (Figures 1A e B). At that time his optic nerve was biopsied, revealing a low-grade glioma with a pilocytic pattern (Figures 2A, B). Adjuvant therapy or postoperative imaging studies were not performed after the biopsy. On examination, the left eye was normal with 20/20 visual acuity. The right eye was grossly proptotic and displaced inferolaterally with a severe limitation of motility in all gaze directions (Figure 2C). Conjunctiva, cornea and anterior chamber were normal, but a dense cataract precluded examination of the fundus. 
There was no light perception and the intraocular pressure was zero. An MRI of the orbits showed an extensive mass in the right orbit extending through an enlarged optic canal (Figures 1C e D). The patient underwent combined neurosurgical and orbital surgery. The optic nerve was incised through a transcranial approach at the chiasma level and the mass was removed by an eyelid- and conjunctiva-sparing orbital exenteration. The orbit was reconstructed with a temporalis transfer and dermis-fat graft (Figure 2D $)^{(4)}$. Histology showed the same pattern as observed in the previous biopsy, i.e., a low-grade pilocytic astrocytoma of the optic nerve.

\section{COMMENTS}

Histologically, gliomas are divided into four types: pilocytic astrocytomas (WHO grade I), low-grade diffuse as- trocytomas (WHO grade II), anaplastic astrocytomas (WHO grade III), and glioblastomas (WHO grade IV) ${ }^{(5)}$. Pilocytic astrocytomas tend to have a favorable prognosis and usually occur in patients less than 20 years of age with neurofibromatosis type I. In patients older than 40 years of age optic nerve gliomas usually differ from the gliomas of childhood. Most adult tumors are highly infiltrative anaplastic astrocytomas or glioblastomas. These neoplasms tend to be aggressive and fatal ${ }^{(6)}$. Our patient was an elderly male who presented the low grade pilocytic pattern of glioma usually observed in children. A Medline search revealed only one report of isolated pilocytic astrocytomas of the optic nerve in an aged adult, as described in this $\operatorname{case}^{(7)}$.

Pilocytic astrocytomas of the optic nerve are typically low-grade neoplasms with a favorable long-term prognosis. Despite incomplete surgical resection, some tumors fail to
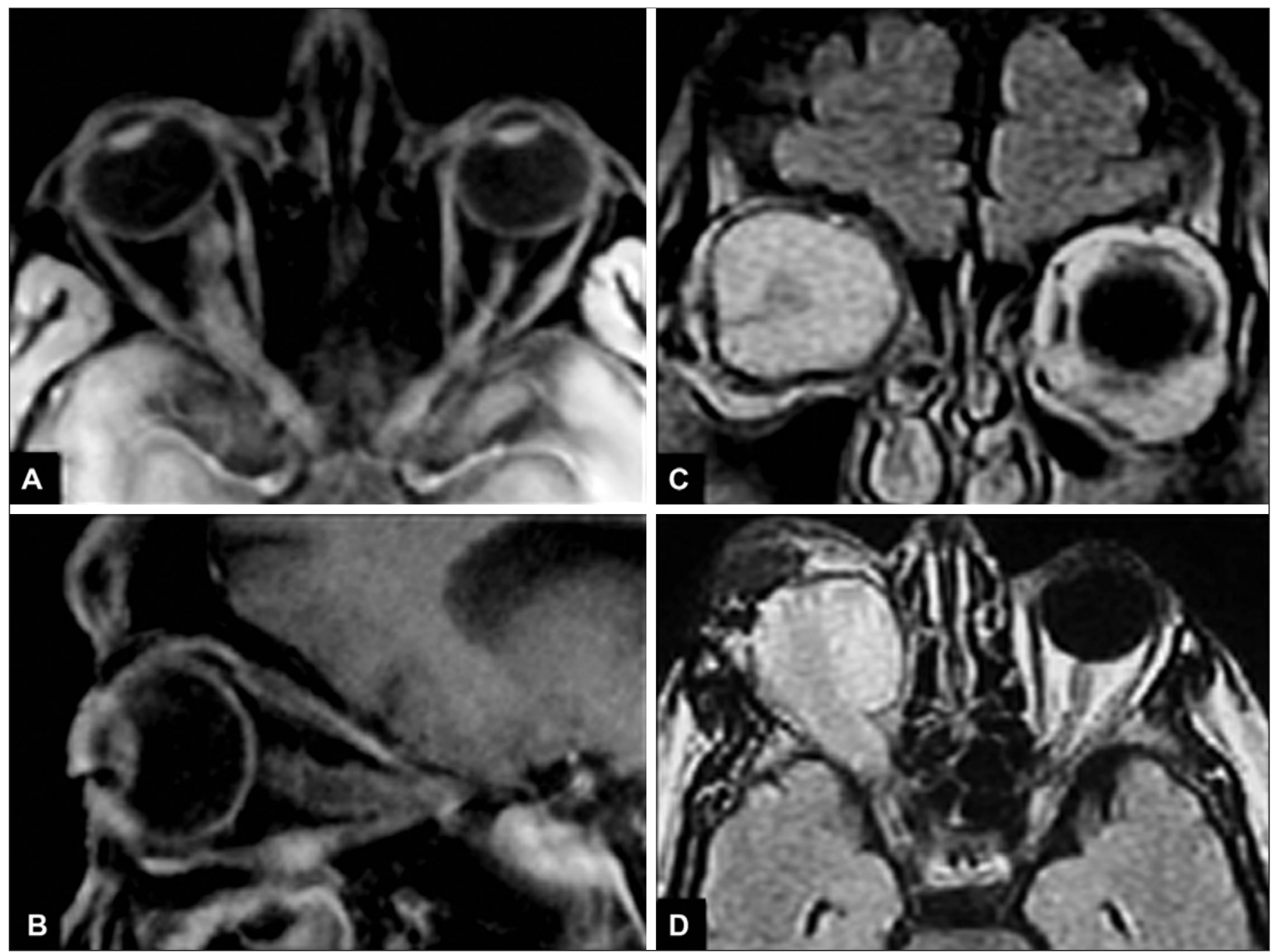

Figure 1 - Orbital magnetic resonance images - preoperative axial (A) and sagital (B) T1 post-enhancement with fat saturation slices showing diffuse enlargement of the right optic nerve. Coronal (C) and axial (D) FLAIR slices presenting a high signal intraconal tumor (recurrence) and enlargement of the optic canal. 

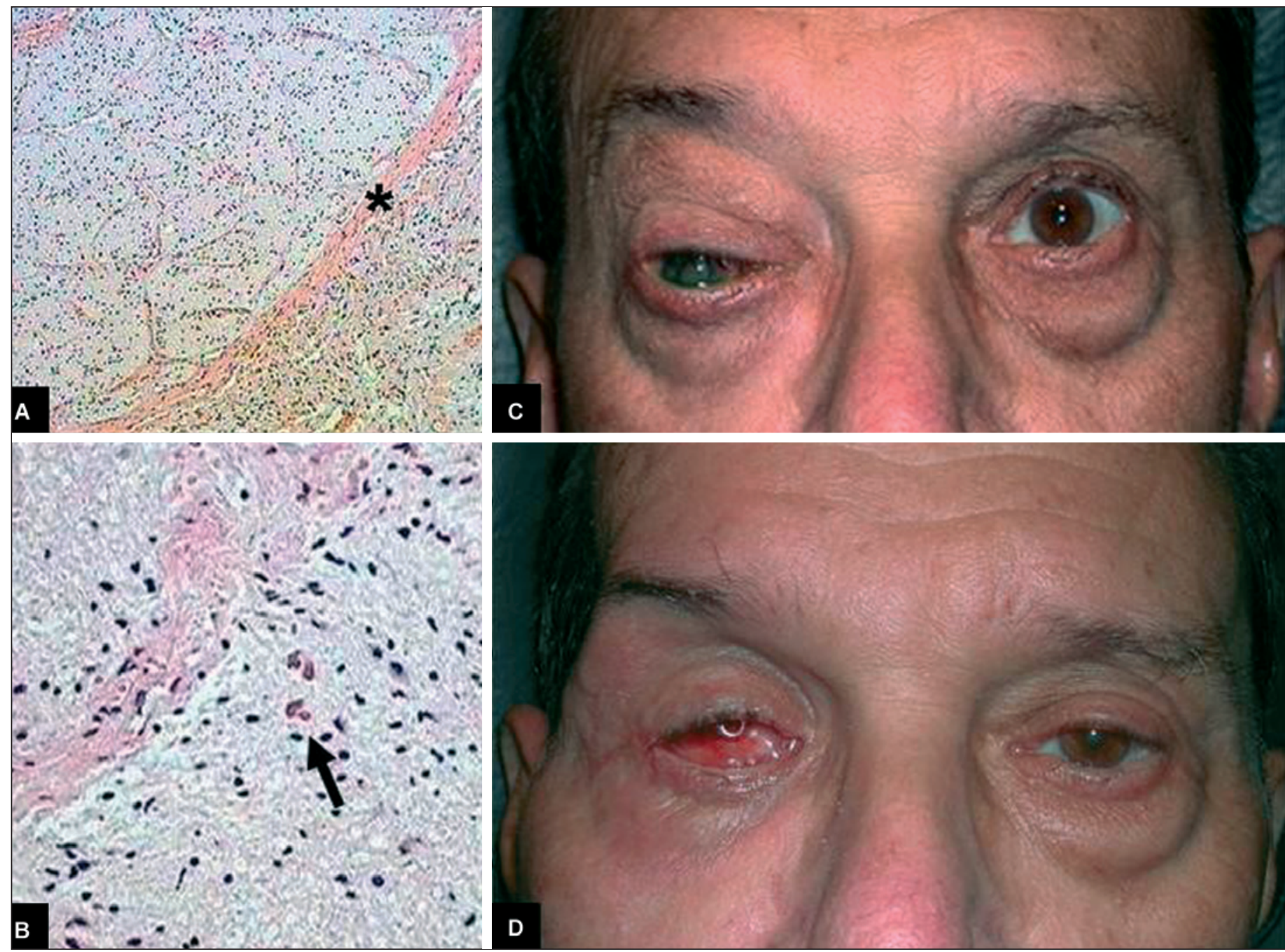

Figure 2 - Histological photographs revealing the optic nerve with neoplastic glial cells, piamater enlargement (asterisk), and Rosenthal fibers (arrow). HEX40 (A); HEX100 (B). Preoperative (C) and postoperative (D) clinical photographs.

recur; suggesting arrest of tumor progression or deceleration of tumor growth ${ }^{(5)}$. In the present case, however, the previous partial excision elicited a rapid recurrence of the tumor in the orbit.

Complete surgical resection is successful in tumors confined to an optic nerve. For disease that has progressed into or beyond the chiasma, total resection is not feasible. Partial resection may provide symptomatic relief and also tissue diagnosis. Radiotherapy (RT) and radiosurgery might be more effective in posterior tumors than surgery alone in preventing relapse, but their morbidity should be taken into consideration. RT alone or after partial resection shows relapse-free rates of $56-90 \%{ }^{(2)}$. Long-term prognosis, however, apparently does not change after any adjuvant treatment ${ }^{(3)}$.

In summary, an isolated pilocytic astrocytoma of the optic nerve in the elderly is a rare event. In the present case, although the tumor had a benign histopathological pattern, partial removal was followed by a rapid growth that warranted a combined neurosurgical and orbital approach.

\section{RESUMO}

Paciente masculino de 68 anos com história de orbitotomia lateral para exérese de tumor no nervo óptico 18 meses antes em outro serviço. O exame histológico demonstrou glioma do nervo óptico com padrão pilocítico. Um ano após, observou-se novo episódio de proptose no olho direito. Ressonância nuclear magnética das órbitas mostrou massa preenchendo quase toda a cavidade orbitária direita com extensão pelo canal óptico até o quiasma. Foi realizada exenteração da órbita direita com excisão da porção posterior do tumor via transcraniana pela neurocirurgia e reconstrução orbitária. A histologia confirmou astrocitoma pilocítico de baixo grau do nervo óptico. 
Descritores: Glioma do nervo óptico/diagnóstico; Astrocitoma/ diagnóstico; Nervo óptico/patologia; Imagem por ressonância magnética; Idoso; Relatos de casos [Tipo de publicação]

\section{REFERENCES}

1. Rush JA, Younge BR, Campbell RJ, MacCarty CS. Optic glioma. Longterm follow-up of 85 histopathologically verified cases. Ophthalmology. 1982;89(11):1213-9.

2. Weiss L, Sagerman RH, King GA, Chung CT, Dubowy RL. Controversy in the management of optic nerve glioma. Cancer.1987;59(5):1000-4.
3. Rootman J. Neoplasia. In: Rootman J, editor. Diseases of the orbit: a multidisciplinary approach. Philadelphia: Lippincott Williams \& Wilkins; 2003. p.213-384

4. Looi A, Kazim M, Cortes M, Rootman J. Orbital reconstruction after eyelidand conjunctiva-sparing orbital exenteration. Ophthal Plast Reconstr Surg. 2006;22(1):1-6.

5. Cummings TJ, Provenzale JM, Hunter SB, Friedman AH, Klintworth GK, Bigner SH, McLendon RE. Gliomas of the optic nerve: histological, immunohistochemical (MIB-1 and p53), and MRI analysis. Acta Neuropathol (Berl). 2000;99(5):563-70.

6. Hoyt WF, Meshel LG, Lessell S, Schatz NJ, Suckling RD. Malignant optic glioma of adulthood. Brain. 1973;96(1):121-32.

7. Wulc AE, Bergin DJ, Barnes D, Scaravilli F, Wright JE, McDonald WI. Orbital optic nerve glioma in adult life. Arch Ophthalmol. 1989;107(7):1013-6.

\title{
XV Congresso Internacional da Sociedade Brasileira de Oftalmologia
}

\section{Encontro Luso-Hispano-Brasileiro}

\section{Encontro França-Brasil}

\section{Encontro Itália-Brasil}

\section{Encontro Latino-Americano}

\author{
2 a 5 de julho de 2008 \\ Windsor Barra Hotel \\ Rio de Janeiro - RJ
}

\section{INFORMAÇÕES \\ Tels.: (21) 3235-9220 • Fax: (21) 2205-2240 e-mail: sbo@sboportal.org.br home page: www.sboportal.org.br}

